\title{
DANSE MACABRE I MUSERNAS HUS - OM MUSEERNAS ROLL OCH VILLKOR IDAG
}

\author{
Kerstin Smeds
}

"Det kommunala museet i lilla Fredriksvaerk i Danmark har gått i konkurs. Konkursförvaltaren hotar att sälja samlingarna av silver, gamla vapen, hantverk och arkeologiskt material, för att kunna betala fordringsägarna... Det är första gängen ett offentligt museum gått $i$ konkurs i Danmark och på den danska motsvarigheten till riksantikvarieämbetet är man djupt skakad. Man hoppas kunna rädda museets samlingar med hjälp av en lag som säger att museer inte fär sälja sina föremål utan godkännande av kulturdepartementet. Konkursförvaltaren hävdar dock, att när museet nu har gått $i$ konkurs, är det konkurslagen som gäller, och han planerar för en auktion."

Det här var en notis i en dagstidning i oktober 2003: Vi fär se hur det går...

Samma dag läser vi en annan insändare i en annan dagstidning:

Vi hör att Historiska museet i Stockholm ställs inför orimliga krav på avgifter för underhåll från Statens fastighetsverk. Men det finns ju en enkel lösning på problemet. Historiska museet har stora samlingar av betydande värde. Varför inte avveckla den museala verksamheten och se till att dyrgriparna säljs på den internationella marknaden? Detta bör ge ett betydande tillskott i statskassan. Den tömda museibyggnaden har ett utmärkt läge och kan förmodligen hyras ut till någon reklambyrå eller annan verksamhet som bättre förmår tillgodose de krav som statens fastighetsverk ställer. En allmänhet som systematiskt berövats sin historia kommer knappast att känna någon saknad. ${ }^{2}$
Denne skribent refererar till den kritiska och alarmerande genomgång av några centrala svenska museers ekonomiska situation som ingick i en av Dagens Nyheters ekonomibilagor i augusti i år. ${ }^{3}$ Den stora stötestenen är de hyror som de stora museerna betalar till sin nuvarande ägare, Statens Fastighetsverk. Är de marknadshyror, så slukar de en alltför stor del av årsbudgeten. Är de såkallade kostnadshyror, som går ut på att museet betalar i princip bara Fastighetsverkets förvaltning och underhåll av fastigheten, så kan de råka illa ut med decennier av eftersatt underhåll som plötsligt skall göras och betalas på ett bräde. Så ligger det till, exempelvis för Historiska museets del. Museet har tillsammans med Fastighetsverket räknat ut att 
de närmaste fyra årens kostnader för underhåll av museibyggnaderna uppgår till 42 miljoner kronor. Detta borde tas från årsanslaget. Plus hyran på $25 \%$ av anslaget. ${ }^{4}$ Eftersom hela årsanslaget uppgår till ca 68 miljoner, säger det sig självt att konkursen i detta fall vore ett faktum.

Jag tänkte nu glänta lite på dörren och kika in i denna museernas kris - för kris kan man tala om, och den gäller inte bara de statliga museerna. Som jag ser det handlar krisen om att den epok som har fött fram museerna, den som framtida historiker kommer att kalla den industriella epoken, nu är slut - eller att vi (här i väst) lever i dess absoluta slutfas. Denna industriella epok, de senaste hundrafemtio eller tvåhundra åren, var också nationalstaternas storhetstid.

Vi som är födda under den västliga, parlamentariska nationalstatens kulmination, 1900talet, är så integrerade i det nationella konceptet att det för oss är närmast omöjligt att tänka oss en värld som inte struktureras i form av nationalstater. Vi inbillar oss gärna att vi lever $\mathrm{i}$ den optimala samhällsordningen. Denna ordning bygger på Upplysningens ideal av demokrati och parlamentarism, folkbildning och jämlikt medborgarskap, där klasskampen i de industriella strukturerna varit drivmotorn. Vi ser denna ordning som utvecklingens och Historiens slut - något annat är inte längre att vänta. Åtminstone ingenting "bättre". Men redan nu styr starka krafter i en riktning mot nationalstatens nedmontering; gränser försvinner, övernationalstatlig parlamentarism tas i bruk, globala nätverk dras kors och tvärs över världen. Europa är på väg mot en federativ organisation, om än under stor vånda och med alla möjliga etniska, nationella och emotionella bromsningsmekanismer. Nationalstaterna kan inte längre garantera välfärdens fortbestånd, knappt ens medborgarnas säkerhet, inte nu längre. Demo- krati, jämlikhet, social trygghet och upplysning har stora, stora marknadsproblem. Nationalstatens storhetstid är över. Nationalstatskonceptet har redan förlorat all betydelse på det ekonomiska området, och informations- och kunskapsområdet står inte långt efter. Även högskolorna internationaliseras, undervisningen konkurrensbeläggs och skyfflas ut på det globala nätet som vilket företag som helst. Språket i denna globala konkurrens är engelska. Förståsigpåarna säger att universiteten i framtiden inte alls kommer att behöva sina byggnader, annat än någon enstaka lokal - klubb - för socialt umgänge. Allt övrigt kommer att ske virtuellt; "levande", audiovisuellt och digitalt förmedlade föreläsningar, samtal och handledning i realtid, på nätet, $\mathrm{i}$ hemmen om man så vill. Man behöver inte ens bo i samma land som man studerar.

\section{VAD FINNS KVAR?}

Kvar finns tillsvidare alla nationalstatens gamla politiska och kulturella institutioner, de gamla hörnstenarna, likt hörnstenarna på ett hus, som gått förlorat av eld eller ålder, men man har velat bevara grunden för eftervärlden. De stora nationella museerna finns bland dessa grundstenar. Men ju mindre behov nationalstaten har av att legitimera sig i form av dylika tunga kultur- och vetenskapshistoriska institutioner, desto svårare blir det att i samhällets politiska toppskikt definiera deras uppgift och roll. Eller att överhuvudtaget försvara deras statliga finansiering. Man vill nog behålla sina gamla institutioner, men vill - och kan inte - betala för dem. Ideologi och praktik har sällan stått så långt från varandra som idag.

Än sedan då?

Vi har redan i ett par decennier levat i en ny fas, en övergångsfas sägs det, som vi kallar informations- eller kunskapssamhället. Om den 
industriella epokens klassamhälle sönderföll (eller åtminstone bytte innehåll) med hjälp av ekonomins globalisering och produktionsarbetets automatisering, har den från och med 1800talets mitt så mödosamt uppbyggda konstruktionen av enhetskultur fallit sönder med hjälp av informationsteknologi och nya medier. ITrevolutionen har brutit sig igenom det kulturella och ideologiska "filter" som de nationalstatliga, enhetskulturella institutionerna utgjort. Vad som helst ur den virtuella världen störtar obehindrat in i våra vardagsrum, var vi än befinner oss geografiskt eller socialt. Vi kan fritt ansluta oss till vilket nätverk vi vill, var som helst i världen. Utbudet av identiteter, "livsstilsgrupper" och subkulturer är ändlöst.

Regionen behöver heller inte längre vara "regional" i förhållande till "centrum", och ha mindervärdeskomplex för det. I den virtuella världen finns ingen periferi. Ej heller centrum. Alla gränser, sociala såväl som kulturella, överskrids utan svårighet.

Nya former av social organisation skapas, som ingenting längre har att göra med det industriella samhällets klasskategorier eller geografiskt och socialt betingade mönster. De här kallas cybernations. De bygger på gemensamma Berättelser, gemensamma etiska värden hos en grupp människor som kommunicerar med varandra via etern. Vi är idag friare än någonsin att välja värderingar och socialgrupp. Cybernations har alltmer börjat ersätta det vi i hundrafemtio år försökte bygga upp som en nationell identitetsskapande enhetskultur, basen för "nationell identitet".

\section{DRÖMSAMHÄLLET}

Vi är alltså redan där. I Dream Society.

När de danska forskarna vid Futurologiska institutet i Köpenhamn för några år sedan fick frågan, vad som kommer efter industrisamhället, var deras svar: Drömsamhället. ${ }^{5}$ När ITrevolutionens smekmånad nu är över, man har nyktrat till och börjat fundera mer på vad slags innehåll alla dessa kanaler och nätverk och virtuella verkligheter skall fyllas med, då har, säger futurologen Rolf Jensen, den globala konkurrensen gått in i ett nytt skede: storytelling. Vi lever i Berättelsernas tidevarv, i fiktionens, drömmens samhälle. Vi träder in i ett nytt Mytens tidevarv. Narrationen har redan länge förberett sin återkomst.

Det är inte längre produkten i sig som är viktig, så som den var i det industriella samhället. Det viktiga är istället vad slags berättelse som medföljer produkten. Det är inte heller ägandet av produkt som är viktigt, ej heller sparandet, uppbevarandet, som i den klassiska industrialismen. Det är brukandet och förbrukandet som är viktigt.

Det är med andra ord Storyn, imagen, som säljer, inte alls produktens "egna" egenskaper. Och med produkt kan man då mena vad som helst från ett par skor till en turistattraktion eller nationalpark, kurs på universitetet eller museum.

Detta har alla marknadsförare lärt sig för länge sedan. Storyn är produkten, och den som har den bästa storyn, vinner marknaden. Och inte bara marknaden, utan folks hjärtan.

På det sociokulturella planet är en typisk sådan ny organisationsform Sverok, Sveriges rollspelsförbund, en på Storytelling byggd skapelse. Där bygger själva grundidén på att man går in i en fiktion, som man upplever som verklig. Samtidigt som man vet att den inte är det. Men det spelar liksom ingen roll. Autenticiteten är inte viktig. Den blir kanske i framtiden allt mindre viktig?

Det är kanske kännetecknande endast för oss sekulariserade själar, som är födda i den klas- 
siska industriella civilisationen, att vi har ett mycket speciellt förhållande till det materiella, till Produkten, till Tinget. Dessa kära Objekt, som vi vill förvärva/tillverka, spara/samla, äga - för att, när vi dör, lämna dem i arv och därmed förlänga oss själva in i evigheten. Vi kan inte leva utan dessa ting. För det andra har vi ett traumatiskt förhållande till Tiden, och därmed Arvet, där ting och tid smälter samman. Vi ser dessa egenskaper som närmast biologiskt betingade, men måste kanske ändå tänka tanken att kommande "virtuella" generationer möjligen inte alls har samma komplicerade förhållande till det materiella, eller till Tiden.

Den telekommunikativa kulturen har dessutom slutgiltigt, får man kanske säga, fört över tyngdpunkten från en klassisk skriftkultur till en visuell kultur, från Texten till Bilden och Ljudet. Det här kan ju uppfattas som en demokratiseringsprocess, som lett till att samhällets elitkultur förlorar mark, och makt. Subkulturernas flora bara växer. Futurologer och filosofer allt från Julia Kristeva till Rolf Jensen talar om stamsamhällets återkomst, där den orala och visuella traditionen och kunskapsöverföringen är viktigare än texten. ${ }^{6}$ "Stammen", "familjen" behöver dock inte längre vara geografiskt förankrad - den kan lika väl bildas på nätet, virtuellt, som en cybernation.

Museerna - dessa nationalstatens tunga bastioner - krälar som maskar i det nationella dammet, i en blandning av identitetsförlust, finansieringssvårigheter och vilja till nyorientering.

Många klamrar sig fast vid de enda roller som man i denna oreda lyckas känna igen: å ena sidan den bevarande/förvaltande rollen, och å den andra den folkbildande, pedagogiska uppgiften. I en tid då skolorna knappast längre undervisar, åtminstone inte i historia, kan denna uppgift vara nog så tacksam för museerna att ta över. Pengar till pedagogik drå- sar in. Men det räcker inte med detta. Om inte museerna (framför allt de stora nationella föremålsmuseerna) förändras, finns det en uppenbar risk att de kommer att försvinna med sin epok. Dödsdansen har bara börjat.

I många länder, t.ex. England och Tyskland, har redan vissa statliga museer såsom Post- och Telemuseerna, blivit tvungna att slå igen sina portar för gott. ${ }^{7}$ De har inte klarat strukturomvandlingarna i samhället, med privatisering och sviktande ideologiskt och politiskt underlag i bakgrunden. En av världens ledande museologer, Peter van Mensch, verksam i Amsterdam, förutspår att mer stängningar kommer att följa innan samhällets strukturomvandlingar är klara med museerna. I England har man bråkat om huruvida Tate Gallery och andra konstmuseer skall få lov att sälja verk ur sina samlingar för att klara finansieringen.

\section{TäNK TANKEN ATT STATEN FAKTISKT SKULLE GE UPP ALLTSAMMANS...}

Privatisering är ett räddningskoncept, som möjligen kan tillämpas på vissa mindre museer, framför allt specialmuseer typ designmuseum, men svårligen på de stora nationella kulturhistoriska museerna, eller stads- och länsmuseer.

Vad händer då om "private enterprise" ändå tar över? "Staten", och den utbildade expertis den matat in i dessa institutioner, förlorar då tolkningsföreträdet, liksom också möjligheten att kontrollera vilket kulturarv som bevaras. Just det här ser somliga som något positivt. En representant för ett privatägt museum i Sydafrika formulerade det såhär: det goda med privatägt är att allt sedan går snabbare, smidigare, och man slipper det evinnerliga tjafset som kravet på politisk och nationell konsensus och demokrati åstadkommer...

Eller kommer staten att behålla denna enda 
kontroll: bevarandestrategierna!? Pengar ges sparsamt till att samla, vårda och magasinera, men föga annat?

Ändå, samtidigt, kräver man redan nu höjda besökssiffror för att legitimera ens den lilla skärv som kommer museerna till del. Alla vet ju vid det här laget att den här ekvationen inte går ihop. Ändå förfasar man sig, när museerna går ut bland företagen och söker sponsorer hymlar och moraliserar över kommersialiseringen av kulturarvet och museerna. Sådant hör inte ihop med de gamla nationalstatliga demokratiska idealen. En mer genomgripande förändring är nödvändig, om museerna skall överleva. I annat fall, stäng dem. Men sluta hymla.

Ett annat scenario är att vissa stora museer måste slå ihop sina påsar och samlingar, på samma sätt som företagen varit tvungna att göra. Kanske Nordiska museet, Historiska museet och Nationalmuseum borde gå samman!? Lägg därtill Etnografiska museet, så har vi det koncept som nestorn inom svensk konsthistoria, Gregor Paulsson, föreslog redan 1920 - inspirerad av ett modernt museiprogram som gavs ut i en skrift: Umgestaltung der Museen im Sinne der Neuen Zeit ${ }^{8}$. Paulsson ville omstrukturera dessa fyra museikolosser i tre nya delar: kvalitetsmuseet, ett hela kulturen sammanfattande museum för den stora allmänheten - en brännpunkt av alla tiders, och gärna länders, kulturer, studiemuseet, för kultur- och konsthistoriker, forskare och specialister, samt de levandes museum detta skulle vara vikt endast för modern konst, och tjäna de nu levande generationernas konstintressen. ${ }^{9}$ Det här är tänkvärt, tycker jag. Kanske med modifikationen att det sista, "de levandes museum", inte bara skulle handla om konst, utan också om allt möjligt nutida som museibesökarna vill hämta in i museet eller se där utställt. Inte mindre tänkvärt är Paulssons förslag för att det är åttiotre år sedan det framfördes.
QUO VADIS, MUSEION?

Varje tid har för vana att klanka på sina museer såsom varande mossiga, trista, grå och tråkiga, med ett ständigt, uppdämt, behov av förnyelse. Men museerna förändras faktiskt hela tiden; det finns mycket trend och mode i musei- och utställningsbranschen. Vi skall komma ihåg att institutionerna är både förmedlare av berättelser och skapare av nya berättelser inom en och samma ram - museet är således ett historiskt handlande subjekt. Museerna inte bara förvaltar kulturarvet, utan omvandlar det också. Och på den punkten har de alltid stått i dialog med samhällsutvecklingen och kulturpolitiken. Inte är museerna särskilt försoffade. Det är staten som är det.

Museernas kris är alltså främst en kulturpolitisk och finansiell kris, som ynglar av sig i identitetskris främst hos de stora gamla nationalmuseerna. Institutionerna står i en politisk korseld mellan gamla instruktioner, som grundar sig på det nationella historiska legitimitetskomplexet, alltså att jobba med det nationella kulturarvet på det klassiska viset, och nya kulturpolitiska uppdrag som handlar om mångkulturalitet, internationellt samarbete, demokrati, främlingsfientlighet, den svagares rätt och annat. Det är där de kulturhistoriska museerna kroknar. Identiteten vacklar. I övrigt saknas varken vilja, idéer eller stora visioner, det ser man ju redan här, om man tar del av Västerbottens museums framtidsplaner.

Skall då den obönhörliga dödsdansen - danse macabre - fortgå? Eller skall man betrakta den som en besvärjelse, exorcism?

Som historiker och museolog måste jag naturligtvis säga att betydligt intressantare än att stänga och montera ned alltihopa är att erkänna att denna nationalstatliga saga nu nått sitt slut, och se sig om efter nya Sagor, köra upp 
nya spår. Visst finns det fortfarande museer, som postulerar som sin främsta uppgift att "samla, vårda, forska och visa", men de är få numera. De flesta museer sysslar i realiteten förvisso med detta, men också med mycket annat.

Den kände, numera framlidne, museimannen Kenneth Hudson skrev redan i mitten av 1980-talet att framtidens museum alltmer kommer att likna ett dynamiskt kulturhus, där samlingar kanske byggs upp, men där alla museets aktiviteter sker $\mathrm{i}$ intim samverkan inte minst med de människor som bor där museet är. Och han anförde ett litet museum i Mexico Citys slumkvarter som ett gott exempel. $\mathrm{Mu}-$ seet, dit lokalbefolkningen släpade sitt eget skrot, sina egna bilder och kära ting, hade blivit den mötesplats för minneshantering, samtidsorientering, lokal historia, identitet och samverkan, som hjälpte invånarna att lyfta upp hela området till ett nytt plan, en ny medvetenhet och stolthet. Barnen tillbringade sina dagar där, de kunde bygga sina egna små utställningar eller bara spela och leka, men de kunde också lära sig läsa där. Kvinnor, som ville fly undan sina fyllbultar till män, samlades där för att söka tröst, arbetslösa likaså, för att diskutera vardagliga problem med varandra. Ibland har dessa "politiskt-sociala" museer inte ens några föremålssamlingar. ${ }^{10}$

Av framtidens museichefer krävde Hudson två egenskaper framom andra: pluralism of interest and the flexibility of imagination. ${ }^{11}$ Museet kommer, i takt med de traditionella massmediernas förtunning, alltmer att axla rollen av samhällskommentator, bli en uttolkare av samtiden, av allt som sker i accelererande tempo i världen av idag. Museet skall förklara världen, och vad det är att vara människa i denna världen. NU. Och samtidigt blottlägga rötterna till alltsammans i det förflutna. Det här uppfattar jag som en mycket positiv utveckling.
Det första vi idag bör erkänna och anpassa oss till är att museet är ett medium, och det finns till för allmänheten, dess primära uppgift är att tjäna samhället och besökarna, däribland också forskarna, inte nationen. Museerna har gått, eller bör gå, över från att vara institution till process. "Processmuseet" är ett tämligen nytt begrepp. Från att vara tingorienterat bör det gå över till att vara funktions- och bruksorienterat.

Det andra vi måste anpassa oss till är den virtuella verkligheten. Det är självklart, att då föremålen i samlingarna genom det digitala mediet kan bli tillgängliga för brukarna på ett helt annat sätt än någonsin förut, till och med tredimensionellt och sensoriskt, måste vi fundera på vad detta har för konsekvenser.

Behövs de autentiska föremålen? Hur? Vi, "industriella epokens" människor, behöver dem som sagt, för oss är autenticitet viktigt, men är det viktigt för våra barnbarn, uppvuxna i flera verkligheter, några av dem helt virtuella? Uppvuxna i en Matrix? För dem är kanske rekonstruktionerna, kopiorna viktigare? Hur såg föremålen ut som nya, eller då de användes? Hur användes de?

Teknikerna talar redan om "dynamisk digitalisering", där innehållet i motsats till den tryckta texten är rörligt, utbytbart, öppet, kanske att jämföra med muntlig tradering av kunskap, ”oral tradition". Det är frågan om direkt kommunikation mellan miljoner människor, öppna forum, där man tillsammans bygger upp berättelser och innehåll. Stories, cybernations. Här kan museet spela en mycket central roll som en spindel. Spindeln som väver nätverk. Museet är samhällets centrala storyteller, kommentator. Samtidigt är det en tidstransformator - förflyttar oss från en tid till en annan och ett slags traderingsstation mellan olika världar och verkligheter, mellan cybernations och 
"vanliga" fysiska verkligheter.

Framtidens institution bör ha en filosofi, och utifrån denna formulera en story - flere storyr, säger Rolf Jensen, och förutspår helt nya yrkesbeteckningar inom institutionerna, såsom "chief adventure officer".

I rak motsats till vad många museer nu klamrar sig fast vid, utropade Kenneth Hudson i en annan artikel, att vi bör skrota begreppet $e d u$ cation! Han konstaterade att det framtida museet inte får bli endast en undervisningscentral. ${ }^{12}$ Det är oftast inte för att söka kunskap som folk kommer till museerna idag - de vet kanske inte ens om vad de kommer dit för, men de söker någonting. Museerna skall vara beredda att erbjuda dem alternativ, också alternativa tankevägar, liksom alternativa verkligheter. "Museums would become, in effect, clubs", säger Hudson.

En fransk forskare ser också det framtida museet som ett slags kulturell och filosofisk klubb, ett café philosophique, där man själv kan söka kunskap och föra lärda samtal med andra. ${ }^{13}$ Museet kan, om vi vill, bli samhällets främsta offentliga Rum.

Museet kan också kombineras med konsertoch teatersalar, biografer. Och det skall vara gratis. Bibliotek är i detta sammanhang ett måste, såsom redan antikens Museion i Alexandria hade. Detta är ett led i framtida ABM-koncept, alltså sammanlänkade eller sammanslagna arkiv-bibliotek-museum. Gärna därtill en Historisk verkstad, där besökarna får skapa sina egna historier, fånga upp förfäders spår, och lämna sina egna spår. Virtuella kuber - cyberverkligheter att gå in i, så som mannen gick in i konstverket och försvann i Sven Lindqvists bok $M y$ ten om Wu Tao-tzu. Där börjar äventyret.

Jag vill avsluta med William Mitchells visioner i hans verk e-topia, om framtidens städer där det museum jag tänker mig får sin givna plats:
De nya modellerna för bebyggelse i det 21 århundradet kommer att karaktäriseras av regioner och småskaliga områden (neighbourhoods) med rikt och livaktigt socialt och kommunalt umgänge på det lokala planet, där liv och rörelse pågår 24 timmar i dygnet, där fotgängaren har makten, där man bygger enheter och byggnadskroppar med vardagsliv, privatliv och arbete samsande under ett tak, och där det sociala livet kompletteras med högtflygande konfigurationer av elektroniska mötesplatser, decentraliserad småskalig produktion, marknadsföring och distributionssystem. ${ }^{14}$

Mitchell talar om virtuell arkitektur och "information superhighways". Han breddar definitionerna av arkitektur och stadsplanering till att gälla virtuella platser lika väl som fysiska, med beaktande av virtuella vägar och kommunikationsleder lika väl som fysiska landsvägar och transportsystem. Det virtuella museet är en realitet, som skall komplettera, expandera och fördjupa det fysiska museet.

Jag vill ha ett museum där man kan gå in, försvinna, och komma ut igen, i en valbar tid, i en valbar verklighet.

\section{Noter}

1. Västerbottens-Kuriren 21.10.03.

2. Gunnar Fransson, Stockholm, i DN 23.10.03.

3. DN 26.8.03.

4. Muntliga uppgifter av museets stabschef $\mathrm{i}$ början av nov. 2003.

5. Rolf Jensen, Dream Society, 1997.

6, Julia Kristeva, Nations without nationalism. Columbia University Press 1993.

7. Stockholms Telemuseum hade inte ännu slagit igen då detta skrevs.

8. Av Vilhelm. R. Valentiner (u.å).

9. Gregor Paulsson, Nya Museer. Ett programutkast. Stockholm 1920.

10. Kenneth Hudson, Museums of Influence, s. 181ff. 11. Ibid. s. 176. 
10 12. "I would very seriously consider abolishing museum education departments as such and converting temperamentally well-suited members of their personnel into peripatetic sources of information, who spend their working time wandering around the museum talking to people." 'This visitors business', GEM News No 61. Återfinns i kompendiet 'Masters Degree Programme, Reinwardt Academy, Museology Department. Amsterdam.' (Odaterat, men använt i undervisningen år 2002).

13. Bernard Déloche, 'Muséologie et philosophie'. ICOM International Council of Museums, ICOFOM, Comité international pour la muséologie. Ed. By Hildegard Vieregg, ICOFOM STUDY SERIES-ISS 31, Coro, Venezuela, Nov.28 - Dec. 04, 1999. Museums-Pädagogisches Zentrum, München 1999. s. 8.

14, William J. Mitchell, e-topia. "Urban life, Jim - but not as we know it". MIT Press 1999 (2.ed. 2000).

\section{SUMMARY}

Danse macabre on the museum scene - notes on the decline and fall of the museum idea

The museum idea in Europe is closely linked to the concept of the nation state. Now that this concept is losing its dominant role, the role of the museum and its public funding is also being questioned. The crisis in societal credibility is foreshadowed by the real or imminent bankruptcy of museums (specific Danish and Swedish instances are quoted in the text). The battle to regain public confidence and approval is well under way. The scene is set for the danse macabre.

Different methods are being chosen. Many museums cling to their traditional functions of preservation and education - and their pedagogical work is most easily accepted, encouraged and subsidized when the space for history teaching in compulsory school is continuously shrinking. Others concentrate on acquiring sponsoring from trade and industry and of course seek support from various foundations.
A regrouping of Swedish national collections was suggested as early as 1920 by Gregor Paulsson to better adapt the museum institution to the needs of contemporary society - into a quality museum (for the general public), a study museum (for researchers) and a museum of the present (to serve the need of future orientation). This was a proposal that pointed the way forward and is still relevant.

The crisis in the museums is principally political and financial resulting in an institutional lack of resoluteness and uncertainty about purpose and societal legitimacy. To survive it will be necessary to acknowledge the end of the national saga and the reality of cybernations and the Dream World, Museums could find their raison d'être serving as dynamic houses of culture, as Kenneth Hudson suggested in the 1980s. The institutions should accept the museum as medium and think of themselves as process-oriented entities whose job it is to support and inspire their communities and visitors/users. They should obviously adapt to the virtual reality produced in a dynamic digital process where the content is similar to an open oral tradition. The museum should be the cultural storyteller and commentator in its community and traditional museum education should be given up in favour of these new roles. According to Kenneth Hudson the museum should become a club, or perhaps - as Bernard Déloche suggests - a café philosophique. Another possible way forward is such cooperation as that promoted in the ABM project where archive, library and museum are amalgamated into a historical workshop.

For the e-topia imagined by William Mitchell the paper concludes with conceiving a museum of the future consisting of a physical building supplemented and expanded to a virtual museum.

Kerstin Smeds, professor i museologi, Umea universitet. Artikeln är hennes installationsföreläsning 8/11 2003. Adr: Institutionen för kultur och medier,

Umeå universitet, S-901 87 Umea

E-post:kerstin.smeds@kultmed.umu.se 